\title{
Leksyka religijna we współczesnych słownikach języka polskiego (nazwy zakonnic i zakonników)
}

\author{
Religious lexis in modern dictionaries of Polish \\ (names of nuns and monks)
}

\author{
Jolanta Migdał \\ Wydział Filologii Polskiej i Klasycznej, Uniwersytet im. A. Mickiewicza w Poznaniu, \\ ul. Fredry 10, 61-701 Poznań, Polska; \\ e-mail: jolamig@amu.edu.pl
}

\begin{abstract}
Agnieszka Piotrowska-Wojaczyk
Wydział Filologii Polskiej i Klasycznej, Uniwersytet im. A. Mickiewicza w Poznaniu, ul. Fredry 10, 61-701 Poznań, Polska;

e-mail: wojaczyk@amu.edu.pl
\end{abstract}

\begin{abstract}
Abstrakt
Celem niniejszego tekstu, będącego kontynuacją naszych rozważań dotyczących funkcjonowania słownictwa religijnego na płaszczyźnie leksykograficznej, jest analiza jednowyrazowych chrześcijańskich nazw zakonnic i zakonników. Materiał badawczy został wyekscerpowany z trzech współczesnych słowników języka polskiego (Słownika języka polskiego pod redakcją Mieczysława Szymczaka, Słownika wspótczesnego języka polskiego pod redakcją Bogusława Dunaja oraz Uniwersalnego stownika języka polskiego pod redakcją Stanisława Dubisza). Na uzyskany z nich zbiór jednostek złożyło się 50 określeń wynotowanych ze słownika pod red. Szymczaka, 32 z dzieła pod red. Dunaja i 52 z ostatniego z wymienionych tytułów (dla porównania - w stanowiącym inspirację do podjęcia przez nas tego zagadnienia Słowniku tematycznym języka polskiego. Człowiek w krainie słów autorstwa Małgorzaty Kity i Edwarda Polańskiego nazw zakonnic i zakonników odnotowano 120). W tekście przeprowadziłyśmy wnikliwą analizę chronologiczną materiału, do czego posłużyły nam liczne opracowania leksykograficzne - od Stownika staropolskiego, Stownika polszczyzny XVI wieku, przez Stownik Lindego, wileński, warszawski, po Praktyczny słownik wspótczesnej polszczyzny pod redakcją Haliny Zgółkowej. Wykazałyśmy również, że w siatce haseł poszczególnych słowników pojawiają się w większości te same jednostki językowe, a także w podobny sposób są one definiowane. Natomiast różnice między słownikami zaznaczają się wyraźniej na płaszczyźnie opisu leksykograficznego, a zwłaszcza dotyczą kwestii kwalifikacji haseł.
\end{abstract}

Slowa kluczowe: leksykografia; metaleksykografia; leksyka religijna; zakonnik; zakonnica.

\footnotetext{
Abstract

The purpose of this text, being a continuation of our considerations concerning the functioning of religious vocabulary in lexicographical context, is the analysis of one-word Christian names of religious nuns and monks. The material for study has been extracted from three modern dictionaries of
} 
Polish (Stownik języka polskiego [Dictionary of Polish], edited by Mieczysław Szymczak, Stownik współczesnego języka polskiego [Dictionary of Modern Polish], edited by Bogusław Dunaj and Uniwersalny słownik języka polskiego [Universal Dictionary of Polish], edited by Stanisław Dubisz). The total number of entries obtained is composed of 50 designations extracted from the dictionary edited by Szymczak, 32 from the volume edited by Dunaj and 52 from the last of the three dictionaries (for comparison - in the dictionary that inspired us to study religious lexis - Stownik tematyczny języka polskiego. Człowiek w krainie słów [The Topical Dictionary of Polish. Man in the Land of Words], by Małgorzata Kita and Edward Polański - there were 120 names of religious nuns and monks). The paper offers a careful chronological analysis of the material with the use of numerous lexicographic studies - from Stownik staropolski [Old-Polish Dictionary], Stownik polszczyzny XVI wieku [Dictionary of Polish of the 16th Century], through Stownik [Dictionary] by Linde, wileński [Dictionary of Vilnius], warszawski [Dictionary of Warsaw], to Praktyczny stownik wspótczesnej polszczyzny [Practical Dictionary of Modern Polish], edited by Halina Zgółkowa. Additionally, the authors indicated that in the network of records of individual dictionaries, the same linguistic units appear most often, and, what is more, they are defined in a similar way. As far as the differences between the dictionaries are concerned, they become more conspicuous in the sphere of lexicographical description, and especially in qualification of entries.

Keywords: lexicography; metalexicography; religious lexis; monk; nun.

W roku 2002 ukazał się w Warszawie pierwszy na polskim rynku leksykograficznym Słownik tematyczny języka polskiego. Człowiek w krainie słów autorstwa Małgorzaty Kity i Edwarda Polańskiego (Kita, Polański 2002). Jak piszą we wstępie autorzy: ,słownik jest skoncentrowany na człowieku (na co zresztą wyraźnie wskazuje podtytuł słownika - JM, APW). Zdecydowaliśmy się na taki wybór dlatego, że jądro języka potocznego ${ }^{1}$ - jak wykazują badania - stanowi człowiek. A zatem również słownictwo potoczne ma charakter antropocentryczny, co metaforycznie wyraża aforyzm Protagorasa Człowiek miara wszech rzeczy. Ujmujemy zarówno sferę somatyczną człowieka, jak i jego psyche. Słownictwo zgromadzone w naszym słowniku pokazuje człowieka jako istotę biologiczną, fizyczną, psychiczną; to homo sapiens, ale też homo faber i homo ludens w szerokim sensie tych określeń" (Kita, Polański 2002: 7). Wydaje się, że można do tej listy dodać jeszcze homo religious. W słowniku znalazł się bowiem dość obszerny rozdział poświęcony leksyce życia duchowego. W tej części zamieszczono między innymi zbiór słownictwa zatytułowany zakony. Znalazły się w nim nazwy chrześcijańskich zakonów, zarówno żeńskich, jak i męskich, dokładnie 120 określeń. Zakonów męskich dotyczy 91 nazw, a żeńskich - 29. Trzeba też zaznaczyć, że 26 określeń stanowią związki wyrazowe, np. bracia mniejsi, ojcowie Świętego Krzyża, Stużebniczki Najświętszej Marii Panny czy zakony Świętego Grobu. Zamieszczona w słowniku leksyka dotyczy nie tylko znanych i współcześnie działających w Polsce zgromadzeń. W słowniku zgromadzono także nazwy związane

${ }^{1}$ Warto w tym miejscu zauważyć, że słownik nie jest zbiorem słownictwa potocznego i chyba takiego założenia nigdy nie było, autorzy nie wspominają niczego na ten temat, termin potoczny pojawił się wyłącznie w tym cytowanym fragmencie wstępu, a nawet pobieżny ogląd zawartego w leksykonie słownictwa - można powiedzieć - wyklucza taką możliwość. 
z zakonami już nie istniejącymi (np. antonici $i^{2}$, felianci $i^{3}$ ) lub takimi, które w naszych kraju nie funkcjonują (np. minimici ${ }^{4}$ ). W tej grupie słownictwa znalazło się też sporo określeń, które stanowią synonimy znanych i używanych nazw, odpowiedniki właściwie $\mathrm{w}$ ogóle niestosowane $\mathrm{w}$ polszczyźnie (np. premonstratensi - czyli norbertanie, wincentki, wincentynki - czyli szarytki).

Tak bogaty zbiór określeń zgromadzeń zakonnych umieszczony w Słowniku tematycznym języka polskiego zainspirował nas do przyjrzenia się temu, jakie nazwy z tego zakresu funkcjonują we współczesnych ogólnych słownikach języka polskiego ${ }^{5}$. Niniejszy tekst jest kontynuacją naszych rozważań dotyczących funkcjonowania słownictwa religijnego na płaszczyźnie leksykograficznej. Tym razem interesują nas jednowyrazowe nazwy zakonnic i zakonników z poszczególnych zgromadzeń zamieszczone w trzech współczesnych słownikach wydawanych po połowie XX wieku i na początku wieku XXI. Są to następujące słowniki: Słownik języka polskiego pod redakcją Mieczysława Szymczaka (SJPS) ${ }^{6}$, Stownik wspótczesnego języka polskiego pod redakcją Bogusława Dunaja (SWJP) oraz Uniwersalny stownik języka polskiego pod redakcją Stanisława Dubisza (USJP) ${ }^{7}$.

Okazuje się, że zbiór nazw zakonnic i zakonników we wspomnianych słownikach jest o wiele uboższy niż zaprezentowany przez autorów słownika tematycznego. SJPS odnotował 50 określeń, w SWJP zamieszczono 32, a w USJP - 52 nazwy. Spójrzmy więc, jakie nazwy znalazły uznanie wśród autorów współczesnych słowników ogólnych. Trzeba zauważyć, że wyraźnie dominują leksemy nazywające przedstawicieli zakonów męskich - 32 w SJPS (64\%), 23 w SWJP (71,81\%), 32 w USJP $(61,54 \%)$.

Najstarszą wśród wszystkich tych nazw ${ }^{8}$ jest leksem kartuz ('członek kontemplacyjnego katolickiego zakonu pustelników założonego w XI wieku przez św. Brunona z Kolonii we Francji, o surowej regule nakazującej m.in. milczenie, we-

${ }^{2}$ Antonici - zakon szpitalny założony w 1095 i zlikwidowany w 1803 roku.

${ }_{3}$ Felianci-zgromadzenie zakonne założone w roku 1577 jako zreformowany odłam cystersów, od roku 1595 samodzielny; kres zgromadzenia nastąpił po rewolucji francuskiej i wojnach napoleońskich.

${ }^{4}$ Minimici - inaczej bracia najmniejsi, eremici św. Franciszka, to zakon katolicki wzorowany na regule franciszkanów.

${ }^{5}$ W naszych rozważaniach wykorzystujemy też materiał zebrany do prac magisterskich, które powstały na studiach filologii polskiej na Uniwersytecie im. Adama Mickiewicza w Poznaniu: Mileny Majewskiej z seminarium prof. Andrzeja Sieradzkiego oraz Błażeja Ostacha z seminarium prof. Anny Piotrowicz.

${ }^{6}$ Pełny wykaz stosowanych skrótów zamieszczony został wraz z bibliografią na końcu artykułu.

${ }^{7}$ Opracowanie nazw zakonów i zgromadzeń zakonnych męskich i żeńskich w Kościele rzymskokatolickim przedstawił Edward Breza w dwóch tekstach zamieszczonych w czasopiśmie „Slavia Occidentalis" (Breza 2012; 2013). Jest to głównie omówienie kwestii genezy i budowy tych określeń, uzupełnione o najważniejsze dane historyczne. Autor nie podjął jednak problematyki dziejów tych nazw, zwłaszcza w odniesieniu do polskiej leksykografii.

${ }^{8}$ Oczywiście zdajemy sobie doskonale sprawę, że poszczególne zakony tworzone były w różnych okresach, stąd też w różnym czasie pojawiały się ich nazwy. Jednak bardzo wiele interesują- 
getarianizm, modlitwę i pracę; w lm nazwa tego zakonu'9), jedyny odnotowany w Stowniku staropolskim z pojedynczym poświadczeniem z XV wieku (Sstp 1960-1962: 3, 248).

Genezę szesnastowieczną, udokumentowaną przez Stownik polszczyzny XVI wiek $u^{10}$, można w pełni przypisać sześciu nazwom ${ }^{11}$. Są to: poświadczony 2 cytatami benedyktyn ('członek zakonu reguły św. Benedykta, założonego w VI wieku, uznającego izolację od świata w klasztorze, całkowite posłuszeństwo wobec przełożonych, obowiązek pracy, wyrzeczenie się wartości prywatnej; członkowie zakonu byli w średniowieczu znani jako kopiści ksiąg; w lm nazwa tego zakonu') (SPXVI 1967: II, 44), bernardyn ('członek zakonu reguły św. Franciszka, zreformowanego przez św. Bernarda; nazwa od zbudowanego w 1543 roku w Krakowie klasztoru pod wezwaniem św. Bernarda ze Sieny; w Im nazwa tego zakonu') z frekwencją 31 użyć (SPXVI 1967: II, 47), jezuita ('członek zakonu założonego w 1534 roku przez Ignacego Loyolę w celu walki z reformacją i obrony papiestwa; zakon prowadzi dziś szeroko zakrojoną działalność oświatową, posiada własne szkoły i uniwersytety; w lm nazwa tego zakonu') z 3 przykładami (SPXVI 1975: IX, 501), wyjątkowo - 1 raz odnotowany karmelita ('członek zakonu katolickiego założonego w epoce wypraw krzyżowych w Palestynie na górze Karmel, przekształconego później w klasztor zakonny dzielący się na dwa odłamy (karmelitów bosych i trzewiczkowych); w Polsce od 1419 roku; w lm nazwa tego zakonu') (SPXVI 1976: X, 142), z kolei bardzo często, ponieważ aż 211 razy poświadczony Krzyżak ('członek niemieckiego zakonu osiadłego w XIII w. na ziemiach polskich, noszący biały płaszcz z czarnym krzyżem; członek zakonu krzyżackiego') (SPXVI 1978: XI, 359-360) oraz 5 razy wyekscerpowany minoryta ('członek zakonu franciszkańskiego (braci mniejszych)') (SPXVI 1982: XIV, 277). Do tej liczby nazw, które potwierdzenie w tekstach znalazły w XVI stuleciu, można z pewnymi zastrzeżeniami dołączyć jeszcze cztery określenia. Są to nazwy zakonników, które zostały wynotowane z szesnastowiecznych tekstów, ale w trochę innej (lub innych) niż współcześnie używana, formie ${ }^{12}$. Taka sytuacja dotyczy nazw: augustyjanus, Augustyn, augustnik - dzisiejszy augustianin ('członek zakonu katolickiego założonego w XIII wieku we Włoszech, opartego na regule

cych nas określeń $\mathrm{w}$ zbiorach leksykograficznych pojawiło się z dużym opóźnieniem zarówno w stosunku do daty powstania zakonu, jak i w stosunku do pojawienia się zgromadzenia w Polsce.

${ }^{9}$ Definicje nazw zakonnic i zakonników pochodzą z ekscerpowanych współczesnych słowników, przeważnie z SWJP; jeśli hasło nie zostało odnotowane w SWJP wykorzystujemy definicje z SJPS lub USJP.

${ }^{10}$ Wykorzystujemy wyłącznie opublikowane dotychczas tomy SPXVI, czyli do tomu XXXVI, a więc do hasła roztyrknać.

${ }^{11} \mathrm{~W}$ tej grupie uwzględniamy te słownikowe hasła, które - chociaż przeważnie udokumentowane w kilku wariantywnych formach (fonetycznych czy słowotwórczych), poświadczone są w XVI źródłach w postaci zgodnej ze współczesną.

${ }^{12}$ Bierzemy tutaj pod uwagę formy różne pod względem słowotwórczym. Nie interesują nas różnice w zapisie, zwłaszcza te, które wynikają z rozwoju polskiej pisowni. 
św. Augustyna') (SPXVI 1966: I, 230), cystercyjens - dzisiejszy cysters ('katolicki zakonnik, członek kontemplacyjnego zakonu wywodzącego się od benedyktynów, założonego w XI wieku przez św. Roberta; w lm nazwa tego zakonu') (SPXVI 1968: III, 726), dominikan, dominik - dzisiejszy dominikanin ('mnich z zakonu założonego w XIII wieku przez Dominika Guzmana; głównym powołaniem zakonu jest kaznodziejstwo, głoszenie rekolekcji, duszpasterstwo w środowiskach akademickich') (SPXVI 1971: V, 327) oraz franciszek, franciszkana - dzisiejszy franciszkanin ('członek katolickiego zakonu żebrzącego założonego przez św. Franciszka z Asyżu; w lm nazwa tego zakonu') (SPXVI 1973: VII, 120-121).

Elektroniczny stownik języka polskiego XVII i XVIII wieku potwierdza, że kolejne stulecia przyczyniły się do niewielkiego wzrostu liczby nazw zakonników i zakonnic. Niestety słownik ten jest wciąż opracowywany i część haseł znajduje się tylko w indeksie. $Z$ interesującej nas grupy nowymi są prawdopodobnie dwie nazwy męskie, wyekscerpowane już z XVII-wiecznych źródeł: kapucyn ('członek zakonu katolickiego o ostrej regule, założonego w XVI wieku jako odłam franciszkanów, zajmującego się głównie misjami i akcjami charytatywnymi') i reformat ('członek zakonu franciszkańskiego istniejącego między XVI a XIX wiekiem (później połączonego z bernardynami), skupiającego zwolenników surowej, pierwotnej reguły św. Franciszka') oraz pochodzący z XVII stulecia - celestyn ('członek dawnego zakonu reguły bernardyńskiej, zreformowanej przez papieża Celestyna V w XIII wieku'), a także trzy w innej niż współczesna formie: bazylian ('członek zakonu opartego na regule Bazylego Wielkiego; początki istnienia tego zakonu w Polsce (XVII wiek) wiążą się z Kościołem unickim (grecko-katolickim); w lm nazwa tego zakonu') z najstarszymi poświadczeniami z końca XVII wieku, bonifratel ('członek zakonu założonego przez św. Jana Bożego w celu opiekowania się chorymi, szczególnie chorymi umysłowo') z poświadczeniami z XVII wieku, bożogrobca ('członek zakonu założonego w średniowieczu w celu strzeżenia grobu Chrystusa (grobu bożego) i doglądania chorych pielgrzymów') z poświadczeniami z XVIII wieku (ESJPXVII/XVIII). Odnotowane też zostały po raz pierwszy w leksykografii zakonne określenia żeńskie: bazylianka ${ }^{13}$ ('członkini zakonu żeńskiego opartego na regule św. Bazylego') z XVIII-wieczną dokumentacją, benedyktynka ('członkini zakonu reguły św. Benedykta') z najstarszymi poświadczeniami z II połowy XVII wieku, bernardynka ('członkini żeńskiego zakonu reguły św. Bernarda, zniesionego w XVIII wieku') z ilustracją cytatową już z początku XVII stulecia, franciszkanka ('członkini żeńskiego zakonu reguły św. Franciszka z Asyżu') z najstarszą dokumentacją pochodzącą ze słownika Abrahama Michała Trotza z 1764 roku. Jak na razie niestety tylko w indeksie zapisano liczną grupę interesujących nas haseł. Są to: cysters, cysterka, dominikan-

13 We współczesnych słownikach (tych ekscerpowanych) nazwa ta zamieszczona jest wyłącznie w USJP. 
ka, kameduła, kapucynka, karmelitanka, paulin, pijar, reformatka, sakramentka, trynitarz i wizytka (ESJPXVII/XVIII).

Dość spora liczba zakonnych określeń odnotowana została dopiero w Stowniku języka polskiego Samuela Bogumiła Lindego w początkach XIX wieku, co świadczy niezbicie, że w polszczyźnie pojawily się one w XVII lub XVIII wie$\mathrm{ku}^{14}$. W tej grupie znalazły się następujące nazwy ${ }^{15}$ : augustianin ('członek zakonu katolickiego założonego w XIII wieku we Włoszech, opartego na regule św. Augustyna') (Linde 1807: I/I, 33), bonifrater ('członek zakonu założonego przez św. Jana Bożego w celu opiekowania się chorymi, szczególnie chorymi umysłowo') (Linde 1807: I/I, 144), bożogrobiec ('członek zakonu założonego w średniowieczu w celu strzeżenia grobu Chrystusa (grobu Pańskiego) i doglądania chorych pielgrzymów') (Linde 1807: I/I, 150), cysters ('katolicki zakonnik, członek kontemplacyjnego zakonu wywodzącego się od benedyktynów, założonego w XI wieku przez św. Roberta; w lm nazwa tego zakonu') (Linde 1807: I/I, 339), kameduła ('członek katolickiego zakonu kontemplacyjnego o surowej regule wymagającej życia pustelniczego, bezwzględnego milczenia i surowych postów; w $1 \mathrm{~m}$ nazwa tego zakonu') (Linde 1808: I/II, 941), miechowita ('członek zakonu bożogrobców założonego w średniowieczu w celu strzeżenia grobu Chrystusa i doglądania chorych pielgrzymów, sprowadzonego w XII wieku do Polski, gdzie organizował szpitale i szkoły') (Linde 1809: II/I, 73), paulin ('członek kontemplacyjnego (pierwotnie - pustelniczego) zakonu założonego około 1250 roku na Węgrzech, opartego na wariancie reguły augustiańskiej') (Linde 1811: II/II, 653), templariusz ('członek zakonu rycerskiego, istniejącego w latach 1119-1312 w Jerozolimie, potem we Francji, którego głównym celem była walka z muzułmanami; w lm nazwa tego zakonu') (Linde 1812: V, 615), trynitarz ('członek zakonu kanoników regularnych Świętej Trójcy, powołanego w 1198 roku we Francji dla wykupywania jeńców chrześcijańskich z niewoli muzułmanów, współcześnie skupiającego się na pracy misyjnej; w lm nazwa tego zakonu') (Linde 1812: V, 668). W dość dużej liczbie, pojawiły się też nazwy zakonnic, a wśród nich: dominikanka (forma żeńska od dominikanin) ${ }^{16}$, karmelitanka ('członkini katolickiego zakonu Matki Boskiej z góry Karmel, założonego w XV wieku, zreformowanego w XVI wieku przez św. Teresę; w lm nazwa tego zakonu') (Linde 1808: I/II, 965), norbertanka ('członkini zgromadzenia zakonnego związanego pod względem reguły i organizacji z norbertanami') (Linde 1809: II/I, 328) oraz wizytka ('członkini założonego w XVII wieku zakonu Nawiedzenia Najświętszej Marii Panny opartego na regule augustyńskiej; salezjanka; w lm nazwa tego zakonu') (Linde

14 S.B. Linde potwierdza hasła cytatami z literatury, jednak nie wszystkie interesujące nas hasła mają takie ilustracje, dlatego trudno określić czas ich zaistnienia w polszczyźnie, a właściwie w tekstach pisanych. Zob. też wcześniejszy przypis.

15 Ważna jest dla nas forma zgodna z dzisiejszą.

16 Jest to definicja z SJPS oraz USJP, w słowniku S.B. Lindego jest: 'zakonnica teyże reguły' jako część artykułu hasłowego Dominik, ... dominikan. 
1814: VI, 253). Warto także zauważyć, że wciąż formy męskie niektórych nazw występują, co poświadcza Linde, bez charakterystycznego w dzisiejszej polszczyźnie rozbudowanego przyrostka -anin, a wyłącznie z sufiksem -an: bazylian (Linde 1808: I/I, 65), dominikan (Linde 1808: I/I, 475), franciszkan (Linde 1808: I/I, 657), norbertan (Linde 1809: II/I, 328). Również dwie nazwy żeńskie odnotowane zostały przez Lindego w innych niż współczesne postaciach; są to elizabetanka (dzisiejsza elżbietanka 'zakonnica ze zgromadzenia św. Elżbiety') (Linde 1808: I/I, 617) oraz urszulka (dzisiejsza urszulanka 'zakonnica ze zgromadzenia zakonnego powstałego w XVI wieku we Włoszech, mającego za główny cel wychowanie dziewcząt') (Linde 1814: VI, 83).

Kolejne dziesięciolecia XIX wieku tylko nieznacznie przyczyniły się do wzrostu liczby nazw zakonnic i zakonników, tych nazw, które funkcjonują we współczesnych słownikach. Świadczy o tym opublikowany w 1861 roku pierwszy podręczny Słownik języka polskiego, zwany słownikiem wileńskim. Znalazły się w nim, nieodnotowane wcześniej hasła męskie: pijar ('w Kościele katolickim: członek zgromadzenia zakonnego, założonego w XVI wieku w Rzymie przez św. Józefa Kalasantego jako stowarzyszenie religijne szkół elementarnych dla ubogich dzieci, zajmującego się działalnością oświatową, reformowaniem i unowocześnianiem szkół średnich; w lm nazwa tego zakonu') (Swil 1961: 2, 1007), redemptorysta ('członek zgromadzenia zakonnego pod wezwaniem Najświętszego Odkupiciela, założonego w 1732 roku w południowych Włoszech przez św. Alfonsa Liguori, zajmującego się głównie prowadzeniem misji parafialnych i rekolekcyjnych; członkowie tego zgromadzenia składają dodatkowy ślub dozgonnego pozostawania w zakonie; w lm nazwa tego zakonu') (Swil 1961: 2, 1345), trapista ('członek kontemplacyjnego zakonu - odłamu cystersów, założonego w 1664 roku, odznaczającego się surową regułą, nakazującą stałe milczenie, oddawanie się rozmyślaniom, ciężkiej pracy i postom; w lm nazwa tego zakonu') (Swil 1961: 2, 1714), a z grupy nazw żeńskich: klaryska ('zakonnica należąca do zakonu typu kontemplacyjnego, o surowej regule, utworzonego przez św. Klarę w XII wieku w Asyżu') (Swil 1961: 1, 492), magdalenka ('członkini zakonu mającego za patronkę św. Magdalenę, założonego w XIX wieku w celu opieki nad moralnie zaniedbanymi dziewczętami') (Swil 1961: 2, 620) i szarytka ('zakonnica należąca do zakonu sióstr miłosierdzia, zajmującego się przede wszystkim chorymi i sierotami; w lm nazwa tego zakonu') (Swil 1961:2, 1619). Po raz pierwszy także wystąpiły w znanej nam współczesnej formie nazwy: bazylianin ('członek zakonu opartego na regule Bazylego Wielkiego; początki istnienia tego zakonu w Polsce (XVII wiek) wiążą się z Kościołem unickim (grecko-katolickim); w lm nazwa tego zakonu') (Swil 1961: 1, 56), franciszkanin ('członek katolickiego zakonu żebrzącego założonego przez św. Franciszka z Asyżu; w lm nazwa tego zakonu') (Swil 1961: 1, 322), norbertanin ('członek zgromadzenia zakonnego kanoników regularnych, założonego przez św. Norberta i opartego na regule św. Augustyna') (Swil 1961: 1, 786), co prawda, wciąż jako formy wariantywne obok wcześniejszych bazylian, franciszkan i norbertan. Co ciekawe, dominikanin jed- 
nak wciąż utrzymywał jako jedyną postać dominikan (Swil 1961: 1, 236). Ciągle też jako wyłączna zanotowana jest forma elizabetanka (Swil 1961: 2, 296).

Podobnie jak Stownik wileński, także Stownik warszawski, czyli Słownik języka polskiego Jana Karłowicza, Adama Kryńskiego i Władysława Niedźwiedzkiego z lat 1900-1927, w niewielkim stopniu wzbogacił odnotowany we współczesnych leksykonach zasób nazw zakonnic i zakonników. W zakresie nazw męskich dotyczy to w pełni tylko jednego określenia: joannita (SW 1902: II, 181). Jako drugą nazwę można uznać po raz pierwszy zastosowane w zgodnej z dzisiejszą formie miano dominikanin, nadal jednak jako obocznik do postaci dominikan (SW 1900: I, 504). Większość nazw zakonnych, które po raz pierwszy spotykamy w Stowniku warszawskim, mieści się w grupie nazw żeńskich. Należą do nich: kapucynka ('członkini zakonu katolickiego o regule św. Franciszka') (SW 1902: II, 252), niepokalanka ('zakonnica zgromadzenia założonego pod koniec XIX wieku w Polsce w celu wychowania dziewcząt') (SW 1904: III, 310), sakrament$k a^{17}$ ('członkini zakonu kontemplacyjnego, zajmującego się głównie modlitwą i adoracją Najświętszego Sakramentu; w lm nazwa tego zakonu') (SW 1915: VI, 9), urszulanka ('zakonnica ze zgromadzenia zakonnego powstałego w XVI wieku we Włoszech, mającego za główny cel wychowanie dziewcząt') (SW 1915: VI, 353), zmartwychwstanka ('członkini polskiego zakonu żeńskiego założonego w XIX wieku w Rzymie') (SW 1915: VI, 551). Tutaj też po raz pierwszy wystąpiła dzisiejsza forma elżbietanka, chociaż nadal z obocznikiem elizabetanka (SW 1900: I, 691).

Pozostałej grupie zakonnych nazw przypisać należy dwudziestowieczną genezę. Dokumentuje to Stownik języka polskiego pod redakcją Witolda Doroszewskiego. Odnotował on po raz pierwszy osiem z zamieszczonych we współczesnych słownikach określeń. Znalazły się tutaj hasła: albertyn ('członek zakonu założonego przez brata Alberta (Adama Chmielowskiego); w lm nazwa tego zakonu') (SJPD 1958: I, 73), katarzynka ('zakonnica zgromadzenia św. Katarzyny, założonego w XVI wieku na Warmii, zajmującego się nauczaniem dziewcząt i pielęgnowaniem chorych') (SJPD 1961: III, 615-616), marianin ('członek zgromadzenia zakonnego, założonego w Polsce w wieku XVIII mającego na celu szerzenie kultu Marii, matki Chrystusa i odprawianie modłów za zmarłych') (SJPD 1962: IV, 457), nazaretanka ('członkini polskiego zgromadzenia zakonnego założonego w XIX wieku, mającego za zadanie wychowanie dziewcząt, pracę w szpitalach i przytułkach') (SJPD 1962: IV, 1281-1282), oblat ('katolickie zgromadzenie zakonne założone w 1816 roku we Francji, zajmujące się głównie wychowaniem młodzieży i pracą misyjną, w którym nie składa się ślubów, tylko przyrzeczenie') (SJPD 1963: V, 468-469), palotyn//pallotyn ('członek katolickiego zgromadzenia

17 Warto zauważyć, że hasło to zilustrowane jest zdaniem: „Maria Kazimiera, żona króla Jana Sobieskiego, sprowadziła sakramentki z Francji do Warszawy roku 1687”. Tym bardziej więc może dziwić, że nazwa ta znalazła się dopiero w Stowniku warszawskim. ESJPXVII/XVIII ma wprawdzie to hasło w indeksie, ale jeszcze nie zostało opracowane. 
zakonnego, zajmującego się czynną działalnością apostolską, np. wydawaniem książek, czasopism katolickich; w lm nazwa tego zgromadzenia') (SJPD 1964: VI, 46), salezjanin ('członek zgromadzenia zakonnego, założonego w XIX wieku przez ks. Jana Bosko, prowadzącego głównie działalność wychowawczą wśród młodzieży; w lm nazwa tego zgromadzenia') (SJPD 1966: VIII, 19), zmartwychwstaniec ('członek polskiego zgromadzenia zakonnego założonego w XIX wieku w Paryżu') (SJPD 1968: X, 1177-1178). Większość tych nazw nie mogła pojawić się o wiele wcześniej, ponieważ zgromadzenia, do których należą określane w ten sposób osoby, powstawały dopiero w XIX lub w XX wieku. Na tym tle dziwić może jedynie tak późne odnotowanie przez leksykografów dwóch nazw: katarzynka i marianin. Marianie, czyli Zgromadzenie Księży Marianów Niepokalanego Poczęcia Najświętszej Maryi Panny, są bowiem pierwszym powstałym na ziemiach polskich w XVII wieku męskim, katolickim zgromadzeniem zakonnym, które zostało założone w 1673 roku przez św. ojca Stanisława od Jezusa i Maryi Papczyńskiego. Interesujące jest to, że już w Słowniku wileńskim w uzupełnieniu definicji hasła pijar wystąpiła nazwa marianie: „Biali pijarowie, in. zowią się Marjanie", jednak nie została ona uwzględniona w siatce haseł tego leksykograficznego zbioru (Swil 1961: 2, 1007). Katarzynki, czyli Zgromadzenie Sióstr św. Katarzyny Dziewicy i Męczennicy, zostało założone na Warmii przez braniewiankę - Reginę Protmann w 1571 roku.

Ostatnia z grupy zakonnych nazw występujących we współczesnych słownikach ogólnych to określenie loretanka ('członkini katolickiego żeńskiego zgromadzenia zakonnego, założonego w 1920 roku w Warszawie, zajmującego się drukowaniem i kolportowaniem książek i prasy, prowadzeniem przedszkoli i domów opieki'). Pojawia się ono tylko w USJP (USJP 2003: 2, 469). Wcześniej znalazło się w Praktycznym słowniku wspótczesnej polszczyzny pod redakcją Haliny Zgółkowej (PSWP 1998: 19, 300).

Dotychczas traktowałyśmy zebrane nazwy zakonnic i zakonników, wyekscerpowane z trzech współczesnych słowników języka polskiego jako zbiór jednolity. Oczywiście, określenia zakonne w poszczególnych leksykonach różnią się głównie liczbą odnotowanych haseł, co sygnalizowałyśmy. Wynika to z faktu, że podobne są zasady doboru czy definiowania słownictwa religijnego. Stąd w siatce haseł poszczególnych słowników pojawiają się w większości te same jednostki językowe, a także w podobny sposób są definiowane. Różnice między słownikami zaznaczają się wyraźniej na płaszczyźnie opisu leksykograficznego słownictwa religijnego, a zwłaszcza dotyczą kwestii kwalifikacji haseł. W odniesieniu do interesujących nas haseł będących nazwami zakonnic i zakonników najczęstszym sposobem sygnalizowania religijnego nacechowania hasła jest informacja $\mathrm{w}$ definicji znaczeniowej odwołująca się do przynależności określanej hasłem osoby do zgromadzenia zakonnego, co jednoznacznie wskazuje na religijny charakter leksemu, np. członek zgromadzenia zakonnego, członkini zgromadzenia zakonnego, zakonnik, członek zakonu, członkini zakonu. W SWJP zwykle zakon czy zgromadzenie zakonne scharakteryzowane jest jako katolickie. W tym słowniku zdarza 
się też w definicji zakresowej wskazanie: „w Kościele katolickim”. Największe różnice wiążą się natomiast z określaniem poszczególnych haseł za pomocą odpowiednich kwalifikatorów. Konsekwentnie, bezwyjątkowo zastosowane zostały kwalifikatory w USJP. Przy każdym interesującym nas haśle wystąpiło określenie rel.[igioznawczy, igijny]. Przy jednym leksemie - templariusz - użyty został, obok wspomnianego, drugi kwalifikator - hist. [oryczny]. Całkiem odmiennie wygląda natomiast użycie kwalifikatorów w dwóch pozostałych słownikach. W obu leksykonach ten sposób charakteryzowania nazw zakonnych jest niezmiernie rzadki. W SJPS kwalifikatory pojawiły się tylko siedem razy (na 50 haseł). Pięciokrotnie zastosowano określenie rel.[igioznawczy, igijny] - przy hasłach: elżbietanka, jezuita, miechowita, salezjanin, trynitarz. Przy definicji reformata użyty został kwalifikator kult. [urowy], a przy haśle joannita - kwalifikator hist.[oryczny]. Jeszcze rzadziej takie kwalifikowanie znalazło zastosowanie w SWJP, co nie powinno jednak dziwić, ponieważ takie było założenie autorów, którzy we wstępnych uwagach pisali: „nie opatrzono [...] kwalifikatorami terminów i znaczeń specjalistycznych, jeśli są one rozpowszechnione, znane przeciętnemu użytkownikowi języka, niespecjaliście" (SWJP: XV). A według autorów uwzględniono słownictwo „wspólne wszystkim odmianom polszczyzny. [...] słownictwo specjalistyczne, ale tylko najbardziej rozpowszechnione, z którym niefachowiec może się zetknąc w tekstach popularnonaukowych, w podręcznikach szkolnych i w prasie" (SWJP: VII). Kwalifikator rel.[igioznawstwo] wystąpił tylko przy trzech hasłach: redemptorysta, szarytka, trapista. Jak można wnioskować, tylko te trzy nazwy uznali autorzy SWJP za specjalistyczne ${ }^{18}$.

Na zakończenie uwag o nazwach zakonnic i zakonników we współczesnych słownikach ogólnych języka polskiego warto podkreślić pewne, wydaje się nam, szczególnie jaskrawe niedociągnięcia i braki w tym zakresie. Pierwsza tego typu uwaga dotyczy zdefiniowania hasła dominikanka, która w dwóch słownikach SJPS i USJP - określona jest dość kuriozalnie jako „forma żeńska od dominikanin”. Definicje innych nazw przedstawicielek żeńskich zakonów rozpoczynają się zawsze słowami członkini zgromadzenia lub zakonnica zgromadzenia. Druga uwaga wiąże się także z nazwami zakonnic. Jak już zauważyłyśmy, leksemy te są w wyraźnej mniejszości. A warto w tym miejscu podkreślić, że według rozmaitych wykazów funkcjonujących w Polsce zgromadzeń zakonnych żeńskich jest o wiele więcej niż męskich. Niewielka liczba nazw zakonnic szczególnie widoczna jest w SWJP, gdzie brakuje choćby właśnie wspominanej przed chwilą dominikanki, mimo że jest i benedyktynka, i franciszkanka, i karmelitanka. We wszystkich trzech słownikach odnotowany został albertyn. Najprawdopodobniej przyczyniła się do tego osoba Polaka - św. Brata Alberta Chmielowskigo, założyciela w 1888 roku w Krakowie zgromadzenia albertynów (pełna nazwa - Trzeci

${ }^{18}$ Można przypuszczać, dlaczego znalazło się w tej grupie takie hasło jak trapista, dziwi jednak szarytka, a już na pewno, w świetle działalności „Radia Maryja” i ojca Tadeusza Rydzyka, redemptorysta. Na tym tle zaskakuje, że inne leksemy nie zostały opatrzone kwalifikatorem, np. trynitarz. 
Zakon Regularny św. Franciszka - Braci Posługujących Ubogim). Współcześnie jednak członków tego męskiego zakonu jest niewielu (w 2009 roku oficjalne dane mówią o 43 zakonnikach). Natomiast żaden z trzech interesujących nas słowników nie zamieszcza hasła żeńskiego albertynka, chociaż to właśnie Zgromadzenie Sióstr Albertynek Posługujących Ubogim jest o wiele liczniejsze i prowadzi bardzo rozwiniętą działalność w 82 placówkach nie tylko w Polsce, ale i za granicą: w Anglii, Argentynie, Boliwii, Rosji (Syberia), na Słowacji, w Stanach Zjednoczonych Ameryki Północnej, na Ukrainie, w Watykanie i we Włoszech.

Podsumowując nasze rozważania na temat nazw zakonnic i zakonników zamieszczonych $\mathrm{w}$ trzech współczesnych słownikach ogólnych języka polskiego, trzeba jeszcze raz przypomnieć prawdy, których, korzystając ze słowników, nie zawsze sobie uświadamiamy. Po pierwsze - każdy słownik odbija w sobie subiektywne przecież spojrzenie autora lub autorów na język i na pozajęzykową rzeczywistość (zob. Bańko 2001: 18; Piotrowska-Wojaczyk 2009: 29). Po drugie - należy pamiętać także o tym, że słowniki, nawet te współczesne, zawsze przedstawiają rzeczywistość pozajęzykową trochę inną, starszą niż ta, w której dany leksykon powstaje i zostaje opublikowany.

\section{Bibliografia}

Bańko M., 2001, Z pogranicza leksykografii i językoznawstwa. Studia o stowniku jednojęzycznym, Warszawa.

Breza E., 2012, Nazwy zakonów i zgromadzeń zakonnych męskich, „Slavia Occidentalis” 69, s. $45-80$.

Breza E., 2013, Nazwy zakonów i zgromadzeń zakonnych żeńskich, „Slavia Occidentalis” $70 / 1$, s. $35-62$.

ESJPXVII/XVIII - Elektroniczny stownik języka polskiego XVII i XVIII wieku, https:// sxvii.pl [dostęp: 24.02.2018].

Kita M., Polański E., 2002, Stownik tematyczny języka polskiego. Człowiek w krainie stów, Warszawa.

Linde S.B., 1807-1814, Stownik języka polskiego, t. 1-6, Warszawa.

PSWP - Praktyczny stownik współczesnej polszczyzny, red. H. Zgółkowa, t. 1-50, Poznań 1994-2005.

Piotrowska-Wojaczyk A., 2009, Opis leksykograficzny stownictwa religijnego na przykładzie wybranych haset, w: Język. Religia. Tożsamość, t. III, red. G. Cyran, E. Skorupska-Raczyńska, Gorzów Wielkopolski, s. 29-37.

SJPD - Stownik języka polskiego, red. W. Doroszewski, t. I-XI, Warszawa 1958-1969.

SJPS - Stownik języka polskiego, red. M. Szymczak, t. 1-3, Warszawa 1978-1981.

SPXVI - Stownik polszczyzny XVI wieku, red. M.R. Mayenowa, F. Pepłowski, K. Mrowcewicz, t. I-XXXVI, Wrocław-Warszawa-Kraków 1966-2012.

Sstp - Stownik staropolski, red. Stanisław Urbańczyk, t. I-XI, Kraków 1953-2002.

SW - Stownik warszawski: J. Karłowicz, A.A. Kryński, W. Niedźwiedzki, Stownik języka polskiego, t. I-VIII, Warszawa 1900-1927.

Swil - Stownik wileński: Stownik języka polskiego, obejmujący: oprócz zbioru właściwie polskich, znaczna liczbę wyrazów z obcych języków polskiemu przyswojonych; nomen- 
klatury tak dawne, jak tė̇ nowo w użycie wprowadzone różnych nauk, umiejętności, sztuk i rzemiost; nazwania monet, miar $i$ wag główniejszych krajów i prowincij; mitologje plemion stowiańskich i innych ważniejszych, tudzież oddzielna tablice stów polskich nieforemnych z ich odmiana; do podręcznego użytku wypracowany przez Aleksandra Zdanowicza, Michała Bohusza Szyszkę, Januarego Filipowicza, Walerjana Tomaszewicza, Florjana Czepielińskiego i Wincentego Korotyńskiego, z udziałem Bronisława Trentowskiego. Wydany staraniem i kosztem Maurycego Orgelbranda, t. I-II, Wilno 1861.

SWJP - Słownik współczesnego języka polskiego, red. B. Dunaj, Warszawa 1996.

USJP - Uniwersalny słownik języka polskiego, red. S. Dubisz, t. 1-4, Warszawa 2003. 